\title{
Clinical Relevance of Type Specific Clays
}

\author{
Bipin B Mishra ${ }^{1 *}$, Kibebew Kibret ${ }^{1}$, Samuel Feyissa ${ }^{1}$ and Richa Roy ${ }^{2}$ \\ ${ }^{1}$ School of Natural Resources Management \& Environmental Sciences, Haramaya University, Ethiopia \\ ${ }^{2}$ Post Graduate Department of Biotechnology, TM Bhagalpur University, Bhagalpur, India
}

Received: October 13, 2017; Published: October 23, 2017

*Corresponding author: Bipin B Mishra, School of Natural Resources Management \& Environmental Sciences, Haramaya University, Ethiopia; Email: bbmsoil@rediffmail.com

\begin{abstract}
Today's life style and food habits are aligned to readymade fast food with challenges in human health safety causing ailments and disorders such as blood pressure, blood sugar, constipation, gastric, weight gain, mental strain etc. They are all responsible to imbalance the life styles. As a result, humans are suffering from varying types of health hazards. Type specific clays are tested at different levels for recovery from such ailments. However, many of such tests are not validated medically, but evidences, being the witnesses of truth, necessitate systematic investigations of type specific clays in soils for their clinical relevance for curing of human ailments and disorders. Clay eating followed by detoxifying potential of clays deserves attention for clinical validation. Ethiopian soils are rich resources for type specific clays that could be tested for clinical uses.
\end{abstract}

Keywords : Clays; Clinical relevance; Human health; Clay eating; Detoxifying potential

\section{Introduction}

Clinical approach refers often to the techniques being applied to the ailment, sickness, disorder and problem in human bodies and requires medical interventions for the purpose of elimination of symptoms in order to restore human health and promote body functioning. Clays have been used for cure of skin infections since long past. Recently, Lynda and Shelley (2010) [16] presented a review report in which the clinical use of French green clay (rich in Fe-smectite) for healing Buruli ulcer, a necrotizing fasciitis ('flesh-eating' infection) caused by Mycobacterium ulcerans is highlighted. The clays are interesting as they may reveal an antibacterial mechanism that could provide an inexpensive treatment for such skin infections (Lynda and Shelley 2010) [16] . A review on Soil Science vs Science for Medicine by Mishra and Richa [1] revealed that clay eating is associated historically with treatment for cholera and bacterial infections. Clay tablets were used widely across the Mediterranean as well as European territories in certain religious cause besides curing the poisoning and the plague. However, the clay tablet was used by Roman Catholic Church and was listed in pharmacopeia as late as 1848. The use of eating clay has been studied in America, Sweden, Africa, Indonesia and Australia. In India and many other countries, however, knowledge on soil and clay eating is scanty. The rates of pregnant women eating soil or clay in African countries range approximately from $28 \%$ in Tanzania to $65 \%$ in Kenya, where clay is selectively identified and sold in markets. They collect it from termite mounds being rich in minerals and eat at an average of $30 \mathrm{~g}$ daily. Important contributions as recorded herein include the reports of Lynda and Shelly (2010) [16] , Wiley and Solomon [2] and Wilson [3]. Present paper is an attempt to understand the clinical relevance of type specific clays in different soil groups across the world including India as well as Ethiopia and other African countries.

\section{Background}

Lynda and Shelley (2010) [16] had arranged type specific clays for clinical uses as follows:

1) Bentonite-type clay has been used to treat infections, indigestion, and other medical problems by both applying clay paste externally to the skin and by ingesting as solution. Bentonite has been prescribed for many dermatologic formulas. Montmorillonite is the main constituent of bentonite.

2) Attapulgite or palygorskite is very absorbent clay, somewhat similar to bentonite. When used in medicine, it physically binds to acids and toxic substances in the stomach and digestive tract. For this reason, it has been used in several anti-diarrheal medications and also as detoxificant.

3) Kaolinite being low activity clay is not as absorbent as most clays used medicinally. It has a low shrink-swell capacity as well as low cation exchange capacity. It is often called 'white cosmetic clay'. However, it is used mainly for oily skins.

Mishra and Richa Roy [1] reviewed the role of soils and clays in protective medical treatments to restore human health. Type specific 
clays are often used on the skin to heal eczema, dermatitis and psoriasis, during bath as a soaking liquid to remove toxins, enrich cells to receive more oxygen, facilitates to alkalize the body and gives relief against digestive problems like constipation, promotes immunity by killing harmful bacteria and viruses, improves teeth, purifies water and is useful as a baby powder alternative as well as for cleaning hair and face. Multani Mitti in India is commonly used for cleaning hair. Advancement in transmission electron microscopes (TEM), field emission scanning electron microscopes (FESEM), atomic force microscopy (AFM), and secondary ion mass spectrometers (SIMS)] have facilitated to undertake investigation on surfaces of clays and similar nano-scale minerals. Efforts are being made to make a clay antibacterial that has not only the potential applications in medicine, but can also contribute to the general understanding of antibacterial mechanisms for permanent cure. Besides, there is emerging interest in geophagy $[3,4]$ to elicit a curing response in humans through ingesting the easily available materials that may physically soothe an infected and inflamed gastrointestinal lining (Lynda and Shetty 2010) [16]. Also, clays are used externally to adsorb toxins from skin and provide heat to stimulate circulation for rheumatism treatment (Lynda and Shetty 2010 [16], Gomes et al. [5]. Historical evidences of using clays are available with Aristotle (384-322 BC) Mahaney et al. [6]. The cure of intestinal ailments by ingestion of volcanic muds is also noticed (Lynda and Shetty 2010[16]). However, evidence indicating antibacterial properties of natural and synthetic clay minerals Herrera et al. [7]; Lynda and Shetty 2010 [16]; Wilson [3] lacks the mechanisms responsible for chemical interaction occurring at the clay mineral-bacterial interface, and that inhibit bacterial growth.

\section{Clay for Detoxification}

Soil and clay eating may be dangerous if anthrax bacteria and others resist for years in the soil. Medical science believes that eating soil or clay would reduce their hunger and sometimes causes infection. Soil is considered to pose hazard because of

a) chemical contamination, especially heavy metals

b) harmful bacteria, mostly from sewage or manure

c) Parasites, especially roundworms from pet or wildlife faeces.

But, taking a pinch of well-tested clay or soil may be a benefit to the immune system. Some reports indicate that normal children of one and three years of age often eat soil, while aged children may continue to eat soil if there is delay in their growth. A dose of $500 \mathrm{mg}$ a day of soil or clay consumption is considered normal in children up to 3 years old as reviewed by Mishra and Richa Roy [1].

Clay may be used externally as well as internally. It is antiseptic to prevent decay or putrefaction, promotes wound healing, relieves and prevents inflammation, cleans cancer cells (anti-carcinogenic), softens and soothens the skin (emollient), refrigerant cools and reduces body temperature (refrigerant) besides improving skin texture (cosmetic). When used internally, the clay such as bentonite acts as a detoxifier, which can absorb heavy metals like mercury, arsenic, lead, and tin. Besides, it provides minerals and trace elements. Being colloidal in nature, it reduces or even eliminates toxins and harmful ingredients from body. Metallic ions of silver, copper, and zinc have inhibitory and bactericidal effects.

The zeolites with their immense power of absorption as well as adsorption indicate strong affinity for oxidized silver ions and thus form silver exchanged zeolites, which have shown antibacterial potential against aerobic and anaerobic Gram-negative and Grampositive bacteria pathogens including Pseudomonas aeruginosa, Porphyromonas gingivalis, Prevotella intermedia, Staphylococcus aureus, Streptococcus mutans, and Streptococcus sanguis and could be used in dental applications Hotta et al. [8], Kawahara et al. [9], Matsuura et al. [10].

Copper-loaded vermiculite is reported to have better antifungal activity besides inhibiting the growth of E. coli Li et al. [11] Clay or soil eating by and large has revealed some potential for digestive and nutritional benefits. However, the most remarkable evidence is its relevance in detoxification. It is known that ingestion of clays by animal species like rats, birds, parrots etc enables a wide variety of foods free of suffering from any toxic effect. Today, human beings are suffering from variety of ailments caused mainly by some types of toxicity/contamination Mishra and Richa [1].

Clays belong to a crystalline shape with hexagonal networks of silicon-oxygen tetrahedron that provides a large surface area with charged sites that cause bonds to capture charged ions and certain toxins. The well known colloidal properties following the existence of hydroxyl ions within the clay structure may promote its ability to bind and exchange other metals, adsorb water and organic compounds. In low concentrations $(4 \mu \mathrm{g} / \mathrm{ml})$, silver ions produced inhibitory and bactericidal effects with no obvious toxic effect on human blood cells Berger et al. [12]. Elevated levels of copper can inhibit the growth of some microorganisms and exhibit bactericidal activity Gordon et al [13]. The use of copper-coated products or copper alloys has been proposed for surfaces exposed to human contact to reduce the transmission of infectious microbial agents. Other metallic oxides, including zinc oxide, magnesium oxide, and calcium oxide, have antibacterial activity with demonstrated effectiveness against E. coli and S. aureus Sawai [14], Mishra and Richa Roy [1,15].

Clay crystals carry a negative electrical charge as hydroxyl and oxide ions, while impurities or toxins or even bacteria carry a positive electrical charge and during exchange with clay, the positively charged ions are attracted to the negatively charged colloidal surfaces of the clays. The clay colloids thus get electrically satisfied and hold the positive ions until human body could remove both through excreta in toilet and accordingly, clay could maintain its colloidal integrity within the human body without any assimilation or break down. The clay may expand in case of montmorillonite or bentonite and the substance could be absorbed by filling the space between the stacked silicate layers. Thus, clay minerals possess an inner layer charge that behaves and acts like an absorbent and may absorb and bond even with elements showing toxic nature. 


\section{Evidence that witnesses the truth of soil/clay eating}

As a mark of the first celebration of the World Soil Day on 5th December, 2014, the Department of Soil Science at Bihar Agricultural University, Sabour in India discovered Karu Paswan of more than 100 years of age at a village of Babupur (Bakharpur) in Pirpainti Block of Bhagapur District in Bihar (India), who has been daily eating a type specific soil of Ganga flood plain for the last 60 years Mishra and Richa [15]. He is non-vegetarian with normal food diet, but daily eats almost $200 \mathrm{~g}$ of soil additionally. He has two daughters and two sons. At this old age, he has black hairs and walks on foot for 10 to $12 \mathrm{~km}$ daily. However, soil sample collected was analysed (Table 1), though further analytical and medical reports are awaited Mishra and Richa Roy $[1,15]$.

Table 1: Chemical analysis of the soil eaten by Karu Paswan.

\begin{tabular}{|c|c|c|}
\hline Parameters & Values & Rating \\
\hline $\mathrm{pH}(1: 2.5)$ & 7.01 & Neutral \\
\hline EC (dS $/ \mathrm{m})$ & 0.036 & Normal \\
\hline Org. C. $(\%)$ & 0.37 & Low \\
\hline P2O5 (kg/ha) & 10.34 & Low \\
\hline K20 (kg/ha) & 371.25 & High \\
\hline Avail.- N (kg/ha) & 112.89 & Low \\
\hline Avail.-S (mg/kg) & 61.71 & High \\
\hline Zn $(\mathrm{mg} / \mathrm{kg})$ & 7.62 & High \\
\hline Cu (mg/kg) & 0.78 & Medium \\
\hline Fe $(\mathrm{mg} / \mathrm{kg})$ & 38.16 & High \\
\hline Mn $(\mathrm{mg} / \mathrm{kg})$ & 24.04 & High \\
\hline Boron $(\mathrm{mg} / \mathrm{kg})$ & 1.10 & High \\
\hline
\end{tabular}

\section{Rays of New Hopes in Ethiopia}

Ethiopia is a land of soil museum covering appreciable areas under dominant clays and clay minerals of volcanic origin namely montmorillonite, attapulgite, zeolite and vermiculite. In patches, kaolin deposits are also observed. Their clinical relevance needs to be established in near future in order to authenticate their medical uses in days to come Mishra and Richa Roy [1,15].

\section{Conclusion}

Soil and clay as the protective medical applications for restoring human health have their long history, which needs to be refined in terms of clinical relevance. Necessity is the mother of invention and challenges often open the door of opportunities. Let's not forget that the soils across the globe suffer from crucial management risks, even though they possess in their type specific forms like clays certain unique potential for medical uses. Soil as a natural resource helps in getting food, water and even air. However, the truth of evidence as recorded is enough to trust on a bare fact that soil or clay may be uniquely suitable medically to cure a number of ailments, which are becoming common to everyone now-a-days across the world.

This is now time for researchers to come forward to establish the truth in a big way in close association with soil science professionals, who could specify the suitability of soil and clay for medical uses.
Soil is thus not only meant for survival and nourishment of human beings, but for protective medical treatment also.

If "Yoga" has been accepted as a symbol to sustain the human health, the clay may be used in clinical application for restoring the human health. However, protocol for clinical uses of type specific clays and even soils is priority and the soil science must address all key issues in course curriculum that suit medical as well as clinical applications.

\section{Acknowledgement}

Thanks to all whose noble contributions have inspired the authors directly or indirectly to complete the manuscript for publication.

\section{References}

1. Mishra BB, Richa Roy (2015a) Soil Science vs Medical Science: Breakthrough in science for medicine. Business of Agriculture pp. 38-41.

2. Wiley AS, Solomon (1998) Geophagy in Pregnancy: A Test of a Hypothesis. Current Anthropology 3(4): 532-545.

3. Wilson MJ (2003) Clay mineralogical and related characteristics of geophagic materials. Journal of Chemical Ecology 29: 1525-1547.

4. Ferrell RE (2008) Medicinal clay and spiritual healing. Clays and Clay Minerals 56(6): 751-760.

5. Gomes CSF, Silva JBP (2007) Minerals and clay minerals in medical geology. Applied Clay Science 36: 4-21.

6. Mahaney WC, Milner MW, Mulyono H, Hancock RGV, Aufreiter S, et al. (2000) Mineral and chemical analyses of soils eaten by humans in Indonesia. International Journal of Environmental Health Research 10(2): 93-109.

7. Herrera P, Burghardt RC, Phillips TD (2000) Adsorption of Salmonella enteritidis by cetylpyridinium-exchanged montmorillonite clays. Vet Microbiol 74(3): 259-272.

8. Hotta M, Nakajima H, Yamamoto K, Aono M (1998) Antibacterial temporary filling materials: the effect of adding various ratios of Ag-Znzeolite. Journal of Oral Rehabilitation 25(7): 485-489.

9. Kawahara K, Tsuruda K, Morishita M, Uchida M (2000) Antibacterial effect of silver-zeolite on oral bacteria under anaerobic conditions". Dental Materials 16(6): 452-455.

10. Matsuura T, Abe Y, Sato Y, Okamoto K, Ueshige M, et al. (1997) Prolonged antimicrobial effect of tissue conditioners containing silver-zeolite. Journal of Dentistry 25.5 (1997): 373-377.

11. Li B, et al. (2002) Antibacterial vermiculite nano-material". Journal of the Minerals Metals and Materials Society. 1: 61-68.

12. Berger TJ, et al (1976) electrically generated silver ions: quantitative effects on bacterial and mammalian cells". Antimicrobial Agents and Chemotherapy 9(2): 357-358.

13. Gordon AS, Howell LD, Harwood V (1994) Response of diverse heterotrophic bacteria to elevated copper concentrations". Canadian Journal of Microbiology 40(5): 408-411.

14. Sawai J (2003) Quantitative evaluation of antibacterial activities of metallic oxide powders $(\mathrm{ZnO}, \mathrm{MgO}$ and $\mathrm{CaO}$ ) by conductimetric assay. Journal of Microbiological Methods 54(2): 177-182.

15. Mishra BB, Richa Roy (2015b) Soil Science Vs Science for Medicine. EC Agriculture 2(5): 454-461.

16. Lynda B. Williams, Shelley E. Haydel (2010) Evaluation of the medicinal use of clay minerals as antibacterial agents. International Geology Review. 52(7-8), 745-770, DOI: http://dx.doi. org/10.1080/00206811003679737 


\begin{tabular}{ll}
\hline BIOMEDICAL & Assets of Publishing with us \\
RESEARCHES & - Global archiving of articles \\
& - Immediate, unrestricted online access \\
& - Rigorous Peer Review Process \\
&
\end{tabular}

